\title{
Uutta tietoa suomen murteiden syntaksista
}

\author{
Milja Väänänen: Subjektin ilmaiseminen \\ yksikön ensimmäisessä persoonassa. Tut- \\ kimus suomen vanhoista murteista. Turun \\ yliopiston julkaisuja C 430. Scripta Lingua \\ Fennica Edita. Turku: Turun yliopisto 2016. \\ 250 sivua (sis. 4 liitettä ja kartan). \\ ISBN 978-951-29-664-6 (PDF).
}

Milja Väänänen tutkii väitöskirjassaan, mitkä tekijät vaikuttavat siihen, ilmaistaanko yksikön 1. persoonan subjekti ainoastaan verbintaivutuksella (esim. väittelen) vai sekä verbillä että pronominisubjektilla (esim. minä väittelen). Tarkastelun kohteena ovat variaatiota mahdollisesti selittävät syntaktis-semanttiset tekijät, mutta niiden lisäksi Väänänen selvittää, onko kyseisessä ilmiössä alueellista vaihtelua. Tutkimusaineistona ovat Lauseopin arkiston murretallenteet, joita hän lähestyy sekä määrällisin että laadullisin keinoin. Aineistonsa puolesta työ kuuluu dialektologian piiriin, mutta tutkimuskohteensa - subjektin - kautta se asemoituu selvästi myös syntaksin kenttään. Teoreettisesti tutkimus ammentaa käyttöpohjaisen kieliopin perinteestä.

Yksikön 1. persoona on kiinnostanut suomen puhekielen tutkijoita viime vuosikymmeninä runsaasti. Yksikön 1 . persoonan pronominien variaatio on ollut yksi eniten tutkituista kielenpiirteistä fennistisessä sosiolingvistiikassa, ja tarkastelun kohteena ovat olleet niin pronominien variaatio kuin niihin kohdistuvat mielikuvat (esim. Nuolijärvi \& Sorjonen 2005; Lappalainen 2011; Mielikäinen \& Palander 2014). Huomattavasti vähemmälle on jäänyt sen selvittäminen, millaisin ehdoin pronominia ylipäätään käytetään ja milloin se jää pois. Väänäsen tutkimusaihe ei ole silti entuudestaan täysin tutkimaton, vaan pronominisubjektin käyttöä ja poisjättöä on jonkin verran selvitetty muutamissa suppeammissa tapaustutkimuksissa (esim. Paunonen 2001; Duvallon 2006; Lappalainen 2006; Helasvuo 2014a, 2014b). Aiemmissa fennistisissä tutkimuksissa pääpaino on ollut kvalitatiivisessa tarkastelussa, mutta aivan pioneerityöstä ei Väänäsen väitöskirjassa ole kyse metodisestikaan, sillä tilastomenetelmiä ja kvalitatiivista analyysiä on yhdistetty jo muutamissa tuoreissa tutkimuksissa (ks. Helasvuo 2014a, 2014b; Helasvuo \& Kyröläinen 2016). Työ tuo kuitenkin esiin runsaasti uutta tietoa ja tarkentaa aiemmissa tapaustutkimuksissa esitettyjä alustavia havaintoja, kuten jäljempänä käy ilmi.

Väitöskirja jakautuu kahdeksaan lukuun. Johdannossa esitellään työn tavoitteet, aineisto ja teoreettinen tausta. Luvussa 2 Väänänen keskittyy subjektin käsitteeseen ja sitä koskevaan aiempaan tutkimukseen. Luvut 3-7 käsittävät analyysin ja tulokset, ja tähän osuuteen sisältyy tutkimuksen keskeisin anti. Luku 3, jossa Väänänen esittelee käyttämänsä tilastomenetelmät sekä koko aineistoon perustuvan kvantitatiivisen analyysin, on näistä otteeltaan kvantitatiivisin, ja sen tulokset toimivat seuraavien lukujen pohjana. Analyysi osoittaa syntaktis-semanttisista muuttujista merkittävimmiksi referentiaalisen etäisyyden, lauseen konjunktioalkuisuuden, sanajärjestyksen sekä verbin syntaktis-semanttisen tyypin - tässä järjestyksessä. Kutakin näistä muuttujista tarkastellaan omassa luvussaan mainitussa järjestyksessä. Luvussa 8 Väänänen kokoaa keskeisimmät tutkimustulokset ja tarkastelee niitä kriittisesti, uusiakin tutkimussuuntia pohtien. Työtä esitellessäni en etene systemaattisesti luku luvulta, mutta käsittelyjärjestys on kyllä varsin lähellä väitöskirjan kronologiaa: tarkastelen ensin työn aineistoa ja menetelmiä, sen 
jälkeen keskeisiä käsitteitä ja lopuksi tuloksia sekä tutkimuksen merkitystä.

\section{Aineisto ja metodit}

Väänäsen käyttämät Lauseopin arkiston murrehaastattelut on kerätty pääosin 1960-luvulla, ja niissä äänessä olevat puhujat ovat varsin iäkkäitä. Kaikkiaan tarkasteltavana on noin 43 tunnin aineisto, joka edustaa monipuolisesti suomen päämurrealueita (n. tunti yhdestä pitäjästä). Vaikka lukijaa houkuttaisi tietää, miten ilmiö edustuu kaikissa suomen murteissa, valittua otosta, johon sisältyy yli 5500 tutkitun ilmiön sisältävää lausetta, voi pitää riittävänä. Murrealueiden jaottelussa Väänänen pitäytyy perinteisessä kahtiajaossa länsi- ja itämurteisiin, mutta toteaa kyllä, että muitakin vaihtoehtoja on esitetty (esim. Paunonen 2006). Aiempia murrejakoja perustellumpi ratkaisu olisi saattanut olla jättää jako auki ja pohtia sitä saatujen tulosten valossa: miten murteet asettuvat laajempiin ryhmiin tutkitun piirteen valossa? Toistaiseksihan meillä on hyvin niukasti tietoa murteiden syntaksista (ks. kuitenkin esim. Kuiri 1984; Ikola, Palomäki \& Koitto 1989; Posio \& Vilkuna 2013), ja aiemmat murrejaot perustuvat lähinnä äänne- ja muotopiirteisiin sekä sanastoon. Murrealueiden nimityksiin ja lyhenteisiin on jäänyt jonkin verran epäyhtenäisyyttä, mutta ymmärrettävyyttä nämä pienet kauneusvirheet eivät haittaa.

Väänäsen väitöskirja laajentaa fennistisen dialektologian kenttää, mutta ennen muuta se edustaa puhekielen syntaksin tutkimusta ja antaa samalla merkittävän panoksen myös yleiskielitieteelliseen keskusteluun subjektin ominaispiirteistä. Teoreettisesti ja metodisesti se ankkuroituu diskurssifunktionaaliseen ja käyttöpohjaiseen kielentutkimukseen. Väänäsen lähtökohtana on ollut aineiston tilastollinen analyysi, jonka pohjalta hän on poiminut tarkemman tarkastelun alle ne ilmiöt, jotka selittävät variaatiota parhaiten. Kvalitatiivisessa analyysissa yksittäisiä esimerkkejä on tarkasteltu niiden vuorovaikutuskontekstissa, ja tavoitteena on ollut tunnistaa varianttien pragmaattisia tehtäviä. Tässä Väänänen hyödyntää vuorovaikutuslingvistiikan ja kognitiivisen kielentutkimuksen käsitteitä ja niiden parissa tehtyä aiempaa tutkimusta. Hän osoittaa tutkimuksellaan hallitsevansa sekä valitsemansa teoreettisen kehyksen että metodiikan. Hän nostaa aiemman tutkimuksen pohjalta hypoteeseja muttei etene sokeasti niitä seuraten vaan tarkastelee lukemaansa kypsän kriittisesti (ks. esim. lukua 4.3 toistovaikutuksesta). Sen sijaan muita kieliä koskevaa tutkimusta olisi voinut pitää esillä enemmänkin. Analyysin tuloksia suhteutetaan kyllä toistuvasti virosta ja espanjasta tehtyyn tutkimukseen, mutta vertailukohdaksi olisi löytynyt tutkimustietoa myös muista, esimerkiksi slaavilaisista kielistä.

Analyysissa vuorottelevat kvantitatiivinen analyysi ja kvalitatiivinen tutkimusote. Tilastollisessa tarkastelussa Väänänen käyttää satunnaismetsämenetelmää, logistista regressiota, päätöspuumenetelmää sekä luvussa 7 korrespondenssianalyysia; ristiintaulukoinnissa hyödynnetään khiin neliö -testiä. Käytännössä monimuuttujamenetelmien käyttö keskittyy lukuun 3, ja muissa luvuissa kvantitatiivinen analyysi perustuu lähinnä khiin neliö -testin tuloksiin. Menetelmät on esitelty havainnollisesti, ja niiden valinta on perusteltu vakuuttavasti. Niitä sovelletaan nähdäkseni asiantuntevasti ja tarkoituksenmukaisesti. Erityisen ansiokasta Väänäsen tutkimuksessa on se, miten tilastollinen analyysi ja konkreettisten diskurssiesimerkkien kvalitatiivinen tarkastelu limittyvät. Kvantitatiivisella analyysilla on seulottu olennaiset muuttujat ja osoitettu niiden väliset painosuhteet. Tutkimus ei jää kuitenkaan tähän, vaan variaation syitä etsitään niistä funktioista, joita lausumilla on kontekstissaan. Työssä esitellään noin 270 esi- 
merkkilausetta tai -katkelmaa, joista Väänänen nostaa esiin perusteltuja huomioita ja näyttää erilaisia tendenssejä.

\section{Keskeiset käsitteet}

Työn keskeisiin käsitteisiin kuuluvat subjekti, nollasubjekti, lause, referentiaalinen jatkuvuus ja konjunktio. Väänänen määrittelee ne perustellen ja käyttää niitä johdonmukaisesti. Kaikki valituista käsitteistä eivät kuitenkaan istu ongelmattomasti puhutun kielen tutkimukseen tai valittuun tarkastelutapaan, ja joissakin tapauksissa kirjoittaja käyttää niitä totutusta poikkeavalla tavalla. Olennaisin näistä poikkeamista on tutkimuksen kannalta hyvin keskeinen nollasubjektin käsite, joka on fennistiikassa perinteisesti yhdistetty nollapersoonaan. Esimerkiksi Isossa suomen kieliopissa määritellään nollasubjekti seuraavasti: "Nollasubjektiksi sanotaan nollapersoonaisten lauseiden ilmipanematonta subjektia, esim. Täällähän jäätyy." (VISK, määritelmät s. v. nollasubjekti, ks. myös $\$$ 1347). Väänänen kuitenkin kutsuu nollasubjektillisiksi myös sellaisia yksikön 1 . persoonan muotoja, joista puuttuu pronominisubjekti ja joissa subjekti edustuu vain verbintaivutuksessa (esim. väittelen). Fennistisessä tutkimuksessa ei nähdäkseni ole aiemmin suomeksi käytetty tässä yhteydessä tätä termiä vaan on puhuttu esimerkiksi ilmisubjektittomuudesta, pro drop -tapauksista ja pronominisubjektittomista tapauksista. Yleiskielitieteellistä tutkimusta ajatellen sen sijaan nollasubjektitermin valinta on aivan luonteva, ja Väänänen tuo myös esiin vakuuttavia perusteluja sille, miksi sama termi sopii sekä yksikön 1. persoonaisten että nollapersoonaisten lauseiden subjektin poissaolon kuvaajaksi (s. 24-29). Lisäksi on myönnettävä, että nollasubjekti on hyvin käytännöllinen termi verrattuna pidempiin ilmauksiin, joilla samaa ilmiötä on kuvattu aiemmin.

Nollasubjektia ongelmallisempiakin käsitteitä työssä tulee vastaan. Ajatuk- sia herättää esimerkiksi se, miten toimiva laskennallisena perusyksikkönä on lause, sillä puhutussa kielessä on tyypillistä, että puheenvuorot voivat rakentua muistakin elementeistä kuin lauseista. Puhekielen keskeisenä syntaktisena yksikkönä pidetty lausumakaan ei kuitenkaan ole tässä tapauksessa lausetta parempi. (Ks. käsitteistä esim Hakulinen 1997: 36-43; Koivisto 2011: 20-30.) Harvassa tapauksessa on helppo keksiä parempaa ratkaisua ottaen huomioon tutkimuskysymykset ja niistä nousevat analyysitarpeet, mutta luvussa 5 konjunktion ja lausumapartikkelin erottelun vaikeuden olisi voinut välttää sillä, ettei konjunktiota olisi käytetty ja-, että-, kun- ja mutta-sanojen yläkäsitteenä vaan niihin olisi viitattu vain sanoina (esim. mutta-sana).

\section{Tulosten tarkastelua}

Vaikka tutkimuskysymyksiä on kaksi - yhtäältä vaihtelua selittävät syntaktis-semanttiset tekijät, toisaalta alueelliset erot -, päähuomion saavat kielensisäiset tekijät, joita tarkastellaan omissa luvuissaan. Merkittävimmäksi vaihtelun selittäjäksi osoittautuu referentiaalinen jatkuvuus, jota tutkitaan tarkastelemalla referentiaalista etäisyyttä eli sitä, miten pitkä välimatka on referentin edelliseen mainintaan tekstissä (ks. lukua 4). Kvantitatiivisesti tätä kuvataan laskemalla, montako lausetta tai vastaavaa diskurssiyksikköä samaviitteisten mainintojen väliin jää. Jos maininnat ovat peräkkäisissä lauseissa, referentiaalinen etäisyys saa arvon 1; jos väliin jää yksi lause, etäisyys on 2 ja niin edelleen. Väänänen osoittaa, että nollasubjekti suosii pientä referentiaalista etäisyyttä. Tarkastelu ei jää kuitenkaan vain tämän toteamiseen, vaan hän näyttää, että tendenssi selittyy sillä, että nollasubjektit esiintyvät lausumissa, joiden keskeinen tehtävä on tarkentaa, korjata ja täydentää edellä sanottua. Väänänen onnistuu myös näyttämään, ettei referenssin vaihdos sinänsä selitä sitä, että pronomini- 
subjekti on tyypillisempi kuin sen puuttuminen, sillä pelkkä verbinmuotokin voi esiintyä tällaisessa asemassa, jos lauseella on merkityksellinen yhteys edellä sanottuun. Näin on esimerkiksi silloin, kun finiittiverbillä on täsmentävä tehtävä.

Toiseksi parhaiten subjektin ja nollasubjektin variaatiota selittää lauseen konjunktioalkuisuus (luku 5). Tarkasteltavina ovat aineistossa neljä yleisimmin lauseen alussa esiintyvää konjunktiota eli että, ja, kun ja mutta. Konjunktioalkuisten lauseiden osalta Väänänen osoittaa oikeaksi sen aiemmissa tapaustutkimuksissa esiin nostetun havainnon, että nimenomaan $j a$-alkuiset lauseet suosivat nollasubjektia. Ero on tilastollisesti merkitsevä verrattuna että-, kun- ja mutta-sanoilla alkaviin lauseisiin. Tulokset ovat kuitenkin vielä tätä hienojakoisempia, sillä edellä mainituilla sanoilla on erilaisia käyttötapoja ja silloin kun ja ja mutta toimivat ennemmin lausumapartikkelina kuin konjunktiona, ne suosivat pronominisubjektia selvästi enemmän kuin ollessaan perinteisessä konjunktiokäytössä.

Tutkimus tarkentaa myös kuvaa siitä, millä tavalla subjektin ilmaiseminen kytkeytyy sanajärjestykseen: Väänänen osoittaa, miten adverbiaalin ja erityisesti objektin leksikaalisuudella on yhteys pronominisubjektin poisjättöön (ks. lukua 6). Tässä analyysissä lähtökohtana on Vilkunan (1989) ja Ison suomen kieliopin (VISK $\$ 1369)$ kenttäkuvausmalli. Kiinnostuksen kohteena Väänäsellä on erityisesti se, onko valinnainen esikenttä miehitetty vai ei, eli tarkastelu kohdistuu lauseen alkuun. Tulokset osoittavat, että ilmisubjektittoman lauseen esikentässä on merkitsevän usein adverbiaali tai objekti; pronominisubjektilauseissa on taas merkitsevästi useammin niin sanottu neutraali sanajärjestys eli esikenttä on tyhjä. Ilmisubjektittoman lauseen esikenttään sijoittuva adverbiaali ja etenkin objekti ovat merkitsevästi useammin täysiä leksikaalisia NP:itä kuin pronomineja tai proad- verbeja. Nämä tendenssit Väänänen liittää sellaisiin käsitteisiin kuin kapea fokus ja suppea reema, joista hän syventää tarkasteluaan päätyen pohtimaan emfaattisuutta (erityisesti vakuuttelua) ja kontrastiivisuutta.

Viimeisessä analyysiluvussa (luku 7) tarkastelun kohteena on verbin syntaktissemanttisen tyypin yhteys subjektin ilmaisemiseen. Pohjana Väänänen käyttää Pajusen (2001) jakoa verbityyppeihin mutta soveltaa niitä omiin tarpeisiinsa. Tulokset osoittavat, että kognitio-, puheja tilaverbit suosivat pronominisubjektia ja että liikeverbien ja transitiivisten muutosverbien yhteydessä nollasubjekti on todennäköisempi kuin edellä mainituissa verbityypeissä. Väänänen testaa myös verbilekseemin yleisyyden vaikutusta, mutta osoittaa, ettei pelkkä frekvenssi ole ratkaiseva tekijä subjektin ilmaisemisen kannalta. Sen sijaan käy ilmi, että samallakin verbillä voi olla useita erilaisia kiteytyneitä käyttöjä, joista toisiin on vakiintunut pronominisubjekti ja toisista ilmisubjekti tyypillisesti puuttuu.

Murre-erojen osalta tutkimuksessa tulee selväksi savolaismurteiden erityisyys suhteessa muihin murteisiin; useissa yhteyksissä myös pohjoispohjalaiset murteet asettuvat samaan ryhmään savolaismurteiden kanssa, eli niissä käytetään vähemmän ilmisubjektia kuin muissa murteissa. Se, että juuri näissä murteissa on vanhastaan käytetty yksinomaisesti kaksitavuista minä-pronominia, on mielestäni varteenotettava selitys - onhan se salientimpi kuin sellaiset yksitavuiset vastineensa kuten mä, mää ja mie. Tätä pronominin muodossa ilmenevää variaatiota Väänänen esittelee havainnollisesti luvussa 3.3.3. Karttaan 3 (s. 65) olisi kuitenkin kannattanut sisällyttää myös elisiomuodot (esim. min_oon).

Subjektin ilmaisukeinojen osalta Väänänen painottaa tulostensa valossa sitä, että puhuttua kieltä edustavassa murreaineistossa on selvästi tyypillisempää 
käyttää kaksinkertaista merkintätapaa, eli sekä subjektipronominia että verbintaivutusta, kuin ilmaista subjektia ainoastaan verbin persoonapäätteellä. Pelkkä persoonataivutus on siis toissijainen ja monessa kontekstissa riittämätön subjektin ilmaisukeino; se useimmiten edellyttää, että subjektin samaviitteinen maininta on lähituntumassa. Tätä laajaan ja perusteelliseen aineistoanalyysiin perustuvaa tulosta voi pitää typologista tutkimusta ajatellen relevanttina tietona.

\section{Lopuksi}

Fennistiikassa puhekielen tutkimuksella on ollut jo toista sataa vuotta vahva asema, mutta viime vuosikymmeniin asti syntaksin tutkimus on ollut siinä paitsiossa. 1980-luvulla alkaneessa vuorovaikutuksen tutkimuksessa kieliopilla on ollut keskeinen sija, ja myös puhekielen syntaksin piirteet ovat olleet kiinnostuksen kohteena (esim. Koivisto 2011). Keskusteluntutkimus on ollut kuitenkin pääosin kvalitatiivista ja tarkastellut pienehköjä aineistokokoelmia. Milja Väänäsen työ vie puhekielen syntaksin tutkimusta eteenpäin osoittamalla, että puhuttuakin kieltä voi tarkastella tilastomenetelmin. Perinteistä syntaksin tutkimuksen kenttää se puolestaan täydentää vahvalla aineistolähtöisyydellään. Tutkimus nostaa esiin käyttötapoja ja tendenssejä, joita tuskin tulisi esiin, jos tarkastelisi vain tutkijan intuitioon perustuvia keksittyjä lause-esimerkkejä. Muun muassa näistä syistä toivonkin, että tekijä saattaisi tutkimustuloksiaan myös kansainvälisen tutkimusyhteisön tietoon kirjoittamalla niistä muillakin kielillä kuin suomeksi. Kokonaisuutena Milja Väänäsen väitöskirja on huolellisesti toteutettu tutkimus, joka kuvaa vakuuttavasti suomen murteiden syntaksia subjektin ilmaisutapojen osalta.

HANNA LAPPALAINEN etunimi.sukunimi@helsinki.fi

\section{Lähteet}

Duvallon, Outi 2006: Milloin pronominisubjekti jää pois puhutussa suomessa? - Anneli Pajunen \& Hannu Tommola (toim.), Kielitieteen päivät Tampereella 19.-20.5.2005 S. 203-217. Tampere: Tampere University Press.

Hakulinen, Auli 1997: Vuorottelujäsennys. - Liisa Tainio (toim.), Keskustelunanalyysin perusteet s. 32-55. Tampere: Vastapaino.

Helasvuo, Marja-Liisa 2014a: Agreement or crystallization. Patterns of 1st and 2nd person subjects and verbs of cognition in Finnish conversational interaction. - Journal of Pragmatics $63 \mathrm{~s}$. 63-78.

_ 2014b: Searching for motivations for grammatical patterns. - Pragmatics $24 \mathrm{~s}$. 453-476.

Helasvuo, Marja-Liisa - Kyröläinen, Aki-Juhani 2016: Choosing between zero and pronominal subject. Modeling subject expression in the $1^{\text {st }}$ person singular in Finnish conversation. - Corpus Linguistics and Linguistic Theory $12 \mathrm{~s}$. 263-299.

Iкola, Osmo - PAlomäki, Ulla Koitto, Anna-KaIs A 1989: Suomen murteiden lauseoppia ja tekstikielioppia. Helsinki: SKS.

KoIvisto, Aıno 2011: Sanomattakin selvää? Ja, mutta ja että puheenvuoron lopussa. Helsinki: Helsingin yliopisto.

Kuiri, Kaija 1984: Referointi Kainuun ja Pohjois-Karjalan murteissa. Helsinki: SKS.

Lappalainen, Hanna 2006: Pronominisubjektin käytöstä ja poisjätöstä Kelan asiointikeskustelussa. - Taru Nordlund, Tiina Onikki-Rantajääskö \& Toni Suutari (toim.), Kohtauspaikkana kieli. Näkökulmia persoonaan, muutoksiin ja valintoihin s. 37-64. Helsinki: SKS.

— 2011: Förändring, variation och variationens funktioner. En fallstudie av varia- 
tionen i bruket av personliga pronomen på en finsk landsbygdsort. - Gustav Bockgård \& Jenny Nilsson (toim.), Interaktionell dialektologi s. 159-197. Uppsala: Institut för språk och folkminnen.

Mielikäinen, Aila - Palander, MarJAT TA 2014: Miten puhutaan murteista? Kansanlingvistinen tutkimus metakielestä. Helsinki: SKS.

Nuolijärvi, Pirkko - Sorjonen, MARJA-LeENA 2005: Miten kuvata muutosta? Puhutun kielen tutkimuksen lähtökohtia murteenseuruuhankkeen pohjalta. Helsinki: Kotimaisten kielten tutkimuskeskus.

Pajunen, Anneli 2001: Argumenttirakenne. Asiaintilojen luokitus ja verbien käyttäytyminen suomen kielessä. Helsinki: SKS.

Paunonen, Heikki 2001: Yksikön 1. persoonan pronominin käyttö Helsingin puhekielessä. - Marianne Blomqvist (toim.), Våra språk i tid och rum. Meddelanden från Institutionen för nordiska språk och nordisk litteratur vid Helsingfors universitet s. 154-168. Helsinfors: Helsingfors universitet.

_ 2006: Lounaismurteiden asema suomen murteiden ryhmityksessä. - Taru Nordlund, Tiina Onikki-Rantajääskö \& Toni Suutari (toim.), Kohtauspaikkana kieli. Näkökumia persoonaan, muutoksiin ja valintoihin s. 249-268. Helsinki: SKS.

Posio, Pekka - Vilkuna, Maria 2013:

Referential dimensions of human impersonals in dialectal European Portuguese and Finnish. - Linguistics 51 s. 177-229. SKS = Suomalaisen Kirjallisuuden Seura. Vilkuna, Maria 1989: Free word order in Finnish. Helsinki: SKS.

VISK = HAKUlinen, AUli - Vilkuna, Maria - Korhonen, Rittta Koivisto, Vesa - Heinonen, Tarja Ristta - Alho, IrJA 2004: Iso suomen kielioppi. Verkkoversio. Helsinki: SKS. http://scripta.kotus.fi/visk (15.3.2017).

\section{Laulaen sujuvaksi kirjoittajaksi?}

Jenni Alisaari: Songs and poems in the second language classroom. The hidden potential of singing for developing writing fluency. Turun yliopiston julkaisuja. Annales Universitatis Turkuensis B 426. Turku: Turun yliopisto 2016. Johdanto 64 s. ja kolme artikkelia.

ISBN 978-951-29-6672-1.

Kielitaito jaetaan tavallisimmin neljään osataitoon: ymmärtämiseen, puhumiseen, lukemiseen ja kirjoittamiseen. Nämä taidot kehittyvät osin yhdessä, osin erikseen (ks. esim. Liu \& Costanzo 2013 ja siinä mainitut lähteet). Opetus ja arviointi voi keskittyä yhteen osataitoon tai vaihto- ehtoisesti hyödyttää useita taitoja samanaikaisesti. Jenni Alisaari nostaa väitöskirjassaan esille kysymyksen laulamisen, laulujen kuuntelun ja laulujen sanojen rytmikkään lausumisen yhteydestä kirjoittamisen sujuvoitumiseen. Lähtökohta on kiinnostava, sillä helposti voisi kuvitella laulujen kehittävän ennemminkin puheen sujuvuutta.

\section{Väitöskirjan osa-artikkelit}

Alisaaren kasvatustieteen väitöskirja koostuu kolmesta artikkelista, jotka on kaikki kirjoitettu yhdessä Leena Maria Heikkolan kanssa, sekä artikkeleita yh- 